\title{
PENGGUNAAN PROTEASE ASPERGILLUS SP. DAN RHIZOPUS SP. DENGAN KONSENTRASI YANG BERBEDA DALAM TAHAPAN UNHAIRING TERHADAP KUALITAS FISIK DAN LIMBAH CAIR PADA PENYAMAKAN KULIT DOMBA
}

\section{THE UTILIZATION OF ASPERGILLUS sp. AND RHIZOPUS SP. PROTEASE AT DIFFERENT CONCENTRATION IN UNHAIRING PHASE OF TANNING ON PHYSICAL QUALITY OF SHEEP LEATHER AND LIQUID WASTE}

\author{
Yunus Syafie $^{1 *}$, Suharjono Triatmojo ${ }^{2}$, dan Ambar Pertiwiningrum ${ }^{2}$ \\ ${ }^{1}$ Fakultas Pertanian, Universitas Khairun, Maluku Utara, Jl. Kampus Gambesi, Kota Ternate Selatan \\ ${ }^{2}$ Fakultas Peternakan, Universitas Gadjah Mada, Jl. Fauna No. 3, Bulaksumur, Yogyakarta, 55281
}

\section{INTISARI}

Penelitian ini bertujuan untuk mengetahui aktivitas proteolitik yang dihasilkan jamur Aspergillus sp. dan Rhizopus sp. dalam tahapan unhairing (buang rambut) pada proses penyamakan kulit domba serta pengaruh penggunaan dengan konsentrasi berbeda, terhadap kuat tarik, kemuluran, suhu kerut, dan kualitas limbah (pH, BOD, dan COD). Materi yang digunakan yaitu 15 lembar kulit domba awetan garam dibagi 2 bagian sepanjang garis lurus punggung sehingga diperoleh 30 lembar kulit, kulit dibagi secara acak menjadi 10 kelompok. Perlakuan terdiri dari dua belas kombinasi yaitu protease dari Aspergillus sp., Rhizopus sp. serta gabungan antara Aspergillus sp. dan Rhizopus sp. dengan konsentrasi protease 2\% (P1), 2,5\% (P2), 3\% (P3), dan sebagai kontrol P0. Proses unhairing secara konvensional menggunakan bahan kimia $\mathrm{Na}_{2} \mathrm{~S}(3 \%)$ dan kapur $\mathrm{Ca}(\mathrm{OH})_{2} 6 \%$ dengan 3 ulangan. Sampel air limbah setelah proses unhairing diambil dan dibawa ke laboratorium untuk uji kualitas. Kulit diproses lebih lanjut menjadi kulit samak glazed. Data yang diperoleh dianalisis menggunakan Rancangan Acak Lengkap pola faktorial $3 \times 4$, apabila berbeda nyata dilakukan uji banding dengan uji Duncan's new Multiple Range Test (DMRT). Hasil uji aktivitas proteolitik paling tinggi adalah gabungan antara protease dari Aspergillus sp. dan Rhizopus sp. yaitu sebesar 1.079,17 $\mu \mathrm{M} / \mathrm{ml} / \mathrm{menit}$, sedangkan protease Aspergillus sp. dan Rhizopus sp. masing-masing memiliki aktivitas proteolitik sebesar 542,96 $\mu \mathrm{M} / \mathrm{ml} /$ menit dan 392,89 $\mu \mathrm{M} / \mathrm{ml} /$ menit. Hasil penelitian menunjukkan bahwa penggunaan protease dengan konsentrasi yang berbeda dapat memberikan efek yang positif terhadap kualitas fisik dan limbah cair proses unhairing kulit domba. Konsentrasi protease 2,5\% dan 3\% dapat meningkatkan nilai kuat tarik dan suhu kerut kulit domba serta menghasilkan kulit yang bersih tanpa ada rambut yang menempel dan struktur serabut kolagen terbuka. Perlakuan protease sangat potensial karena dapat menekan angka BOD dan COD limbah sebesar 69\%. Tidak terjadi interaksi antara konsentrasi protease dan sumber protease dalam penelitian ini.

(Kata kunci: Protease Aspergillus sp. dan Rhizopus sp., Unhairing, Konsentrasi, Kualitas fisik kulit, dan Limbah cair)

\section{ABSTRACT}

This research was done to study the activity of protease which produced from Aspergillus sp. and Rhizopus sp. and also the effect of it utilization at different concentration in unhairing phase of tanning on the power of pulling, flexibility and temperature of curl of sheep leather and also the quality of waste ( $\mathrm{pH}, \mathrm{BOD}$ and COD). The matterial that used were 15 slices of sheep leather which was preserved with salt, then cut into two parts that resulting 30 slices. The leathers were divided randomly into 10 groups. The treatment consists of 12 combinations, namely: protease from Aspergillus sp., from Rhizopus sp. and the combination of Aspergillus sp. and Rhizopus sp. with protease concentration were: $2 \%, 2,5 \%, 3 \%$, as the control was the conventional unhairing process by using chemical material $\mathrm{Na}_{2} \mathrm{~S}$ (3\%) and lime $\mathrm{Ca}(\mathrm{OH})_{2}(6 \%)$. After unhairing process, the liquid waste samples were taken and be brought to the laboratory for quality analysis. The leather then were processed to become tannin leather. Obtained data were analyzed using variance analysis of 3x4 factorial of Completely Randomized Design and followed by Duncan's new Multiple Range Test (DMRT). The result showed the highest proteolysis activity was the combinations of protease of Aspergillus sp. and Rhizopus sp. (1.079,17 $\mu \mathrm{M} / \mathrm{ml} /$ minute). While the protease of Aspergillus sp. and Rhizopus sp. activity respectively were $542.96 \mu \mathrm{M} / \mathrm{ml} /$ minute and $392.89 \mu \mathrm{M} / \mathrm{ml} /$ minute. Utilization of protease in different concentration gave positive effect on physical quality and liquid waste in unhairing process of sheep leather tanning. The protease concentration of $2.5 \%$ and $3 \%$ increased the value of pulling power and the temperature of curl. The protease treatment was very potential because it reduce the BOD and COD of waste as much as 69\%. However no interaction between protease concentration and protease resources in this research.

(Key words: Protease Aspergillus sp. and Rhizopus sp., Unhairing, Concentration, Physical quality of leather and Liquid waste)

\footnotetext{
* Korespondensi (corresponding author):

Telp. +62 8219565 2515, E-mail: unu.syafie@yahoo.com
} 


\section{Pendahuluan}

Unhairing atau proses buang rambut adalah tahapan proses yang biasa dilakukan oleh industri penyamakan kulit, setelah proses soaking. Secara konvensional proses ini menggunakan bahan kimia berupa $\mathrm{Na}_{2} \mathrm{~S}$ dan $\mathrm{Ca}(\mathrm{OH})_{2}$ yang bertujuan untuk menghilangkan epidermis, rambut, kelenjar keringat, kelenjar minyak serta mempermudah pelepasan subkutis serta saponifikasi lemak. Penggunaan bahan kimia tersebut selain memperbesar beban cemaran dalam limbah sulfida juga menyebabkan limbah rambut menjadi terpotong sehingga sulit dipisahkan dari limbah cair.

Enzim merupakan salah satu alternatif yang dianggap bisa menggantikan berbagai proses kimiawi dalam suatu produk sehingga menciptakan produk yang ramah lingkungan. Protease merupakan enzim yang penting dan memiliki nilai ekonomi yang tinggi karena aplikasinya sangat luas. Hasil penelitian menjelaskan bahwa jamur Aspergillus sp. dan Rhizopus sp. mempunyai aktivitas proteolitik pada kisaran $\mathrm{pH} 8-10$ dan suhu $40-50^{\circ} \mathrm{C}$ (Triatmojo et al., 2004; Ediari et al., 2002). Secara teoritis enzim yang dihasilkan oleh kedua jamur ini dapat digunakan sebagai agensia unhairing pada proses penyamakan kulit.

Tujuan penelitian ini untuk mengetahui sifat proteolitik yang dihasilkan oleh protease isolasi dari Aspergillus sp. dan Rhizopus sp., serta pengaruh penggunaan dengan konsentrasi berbeda terhadap kuat tarik, kemuluran, suhu kerut, histologi kulit, dan kualitas limbah cair dalam tahapan unhairing pada proses penyamakan kulit. Hasil penelitian ini diharapkan dapat memberikan pengetahuan kepada masyarakat di bidang industri kulit dengan memanfaatkan protease Aspergillus sp. dan Rhizopus sp. sebagai agensia unhairing pada proses penyamakan kulit.

\section{Materi dan Metode}

Penelitian ini dilaksanakan selama sebelas bulan. Pengujian aktivitas protease dan pembuatan masa jamur dilakukan di Laboratorium Teknologi Hasil Ikutan Ternak dan Lingkungan, Fakultas Peternakan, Universitas Gadjah Mada. Proses penyamakan dan uji kualitas fisik dilaksanakan di Balai Besar Kulit, Karet, dan Plastik (BBKKP) Yogyakarta. Pembuatan preparat histologi dilakukan di Fakultas Kedokteran Hewan, Universitas Gadjah Mada, sedangkan untuk pengujian limbah cair berupa BOD, COD, dan sulfida dilaksanakan di Balai Teknik Kesehatan Lingkungan, Yogyakarta.
Alat yang digunakan selama penelitian adalah spektrofotometer, waterbath, autoklaf, oven, drum penyamakan, blender, tensile strength meter, tabung reaksi, cawan petri, tabung erlenmeyer, pipet volume, beker glass, gelas ukur, kertas whatman no 1, kertas saring, timbangan analitik, ose, lampu bunsen, besek, dan $\mathrm{pH}$ meter.

Bahan yang digunakan adalah kulit domba lokal awetan garam dengan spesifikasi umur dan jenis kelamin yang sama sebanyak 15 lembar serta kultur stater Aspergillus sp. dan Rhyzopus sp., Potato Dextrose Agar (PDA), NaCl, kaolin, kapur, natrium sulfida $(\mathrm{NaS})$, asam sulfat, asam forminat, larutan garam mineral $\left(\mathrm{NaNO}_{3}, \mathrm{KH}_{2} \mathrm{PO}_{4}\right.$, $\mathrm{MgSO}_{4} .7 \mathrm{H}_{2} \mathrm{O}, \quad \mathrm{KCl}, \quad \mathrm{FeSO}_{4} \cdot 7 \mathrm{H}_{2} \mathrm{O}$, dan $\mathrm{ZnSO}_{4} \cdot 7 \mathrm{H}_{2} \mathrm{O}$ ), Trichloro Acetic Acid (TCA), tirosin, buffer glisin $\mathrm{NaOH} \mathrm{pH} 9,5$, asam formiat $10 \%$, dan bahan penyamak.

Penelitian ini dilakukan melalui dua tahap, pada tahap pertama dilakukan karakterisasi enzim protease yang dihasilkan oleh jamur Aspergillus sp. dan Rhyzopus sp., sedangkan tahapan kedua dilakukan aplikasi enzim protease sebagai agensia unhairing pada proses penyamakan kulit.

Kulit domba sebanyak 15 lembar dibelah 2 sehingga diperoleh 30 belahan yang digunakan sebagai obyek percobaan tahapan unhairing (buang rambut). Kemudian diaplikasikan ke dalam 4 perlakuan dimana $\mathrm{P}_{0}$ (kontrol), $\mathrm{P}_{1}, \mathrm{P}_{2}$, dan $\mathrm{P}_{3}$ buang rambut dengan protease Aspergillus sp., Rhyzopus sp. dan kombinasi keduanya dengan masing-masing konsentrasi enzim sebanyak $2 \%, 2,5 \%$, dan $3 \%$.

Secara enzimatis unhairing atau buang rambut dilakukan dengan cara mengoleskan kulit dengan pasta yang terdiri dari $7 \%$ kaloin dan enzim sesuai dengan perlakuannya, $\mathrm{pH}$ diatur menjadi 9,5 dengan penambahan kapur kemudian didiamkan selama 20 jam. Kulit diputar dalam drum penyamakan yang berisi $100 \%$ air, kemudian dilanjutkan dengan buang rambut. Selanjutnya sampel air limbah diambil untuk dianalisis $\mathrm{pH}, \mathrm{BOD}$, dan COD. Kemudian proses dilakukan secara bersamasama pada tahapan penyamakan hingga diperoleh kulit samak untuk pengambilan sampel pengujian fisik.

\section{Analisis data}

Data kualitas fisik kulit dan limbah cair dianalisis secara statistik menggunakan analisis variansi dengan menggunakan Rancangan Acak Lengkap pola faktorial $3 \times 4$, jika terdapat perbedaan antara perlakuan akan dilanjutkan dengan uji Duncan's new Multiple Range Test (DMRT), sedangkan data aktivitas enzim dan histologi kulit dijelaskan secara deskriptif. 


\section{Hasil dan Pembahasan}

\section{Aktivitas enzim}

Aktivitas protease yang diperoleh dari hasil penelitian ini menunjukkan bahwa isolat jamur yang memiliki aktivitas proteolitik paling tinggi adalah gabungan antara jamur Aspergillus sp. dan Rhizopus sp. yaitu sebesar $1.079,17 \mu / \mathrm{mg}$ protein, sedangkan untuk jenis jamur Aspergillus sp dan Rhizopus sp masing-masing memiliki aktivitas proteolitik sebesar 542,96 dan $392,89 \mu / \mathrm{mg}$ protein.

\section{Kuat tarik kulit}

Hasil analisis variansi menunjukkan bahwa konsentrasi enzim protease mempunyai pengaruh yang sangat nyata $(\mathrm{P}<0,01)$ terhadap kuat tarik kulit, sedangkan jenis jamur memberikan pengaruh yang nyata $(\mathrm{P}<0,05)$ terhadap kuat tarik kulit. Penggunaan Aspergillus sp. Rhizopus sp. serta kombinasinya, terutama pada perlakuan $2,5 \%$ dan $3 \%$ memacu peningkatan aktivitas enzim protease dalam memecah protein globular (non kolagen). Konsentrasi enzim semakin besar membuat kerja enzim semakin optimal untuk menghidrolisis protein non kolagen sehingga menyebabkan struktur jaringan kulit menjadi lebih terbuka dan bahan penyamak lebih mudah berinteraksi dengan kulit dan menghasilkan nilai kuat tarik semakin tinggi.

Perbedaan jenis jamur penghasil protease berpengaruh nyata terhadap nilai kuat tarik kulit. Protease yang dihasilkan oleh kombinasi jamur Aspergillus sp. dan Rhizopus sp. serta jamur Aspergillus sp. mempunyai akitvitas lebih tinggi dibandingkan dengan Rhizopus sp. Triatmojo et al. (2004) menyatakan bahwa aktivitas enzim protease yang dihasilkan oleh jamur Aspergillus sp. adalah 13,61 U/mg, sedangkan Widowati et al. (2002) melaporkan bahwa protease yang dihasilkan oleh Rhizopus sp. adalah 8,57 U/mg. Besarnya aktivitas protease yang dihasilkan membuat kerja enzim lebih optimal untuk menghidrolisis protein non kolagen sehingga menyebabkan struktur jaringan kulit menjadi lebih terbuka dan bahan penyamak lebih mudah berinteraksi dengan kulit sehingga menghasilkan nilai kuat tarik yang tinggi. Keseluruhan nilai rerata kuat tarik pada penelitian ini mempunyai nilai di atas batas minimum yang diperbolehkan dalam SNI 06-0234-1989 yaitu 150 $\mathrm{kg} / \mathrm{cm}^{2}$. Interaksi antara faktor konsentrasi enzim dan jenis jamur penghasil protease terhadap kuat tarik kulit domba memberikan perbedaan yang tidak nyata.

Tabel 1. Rerata nilai kualitas fisik kulit samak proses unhairing menggunakan enzim protease Aspergillus sp., Rhizopus sp. serta gabungan Aspergillus sp. dan Rhizopus sp. (average of physical quality of tannin leather that using protease of Aspergillus sp., Rhizopus sp. and combined of them on unhairing process)

\begin{tabular}{|c|c|c|c|c|c|}
\hline \multirow{2}{*}{ Parameter } & \multicolumn{4}{|c|}{ Perlakuan (treatment) } & \multirow{2}{*}{$\begin{array}{c}\text { Rerata } \\
\text { (average) }\end{array}$} \\
\hline & $\mathrm{P} 0$ & $\mathrm{P} 1$ & $\mathrm{P} 2$ & $\mathrm{P} 3$ & \\
\hline \multicolumn{6}{|c|}{ Kuat tarik $\left(\mathrm{kg} / \mathrm{cm}^{2}\right)\left(\right.$ pulling power $\left.\left(\mathrm{kg} / \mathrm{cm}^{2}\right)\right)$} \\
\hline Aspergillus sp. & 154,90 & 161,57 & 196,22 & 220,24 & $183,23^{\mathrm{a}}$ \\
\hline Rhizopus sp. & 157,46 & 157,90 & 187,88 & 206,50 & $177,44^{\mathrm{b}}$ \\
\hline Aspergillus sp. + Rhizopus sp. & 157,46 & 161,57 & 196,22 & 220,24 & $183,87^{\mathrm{a}}$ \\
\hline Rerata (average) & $156,61^{\mathrm{c}}$ & $160,35^{\mathrm{c}}$ & $193,44^{b}$ & $215,66^{\mathrm{a}}$ & \\
\hline \multicolumn{6}{|l|}{ Kemuluran (\%) (flexibility (\%) $)^{\mathrm{ns}}$} \\
\hline Aspergillus sp. & 40,00 & 39,33 & 38,00 & 37,33 & 38,67 \\
\hline Rhizopus sp. & 38,00 & 40,67 & 37,33 & 36,67 & 38,17 \\
\hline Aspergillus sp. + Rhizopus sp. & 38,00 & 39,33 & 38,67 & 36,67 & 38,17 \\
\hline Rerata (average) ${ }^{\mathrm{ns}}$ & 38,67 & 39,78 & 38,00 & 36,89 & \\
\hline \multicolumn{6}{|c|}{ Suhu kerut kulit $\left({ }^{\circ} \mathrm{C}\right)\left(\mathrm{curl}\right.$ temperature $\left.\left({ }^{\circ} \mathrm{C}\right)\right)$} \\
\hline Aspergillus sp. & 113,00 & 111,67 & 116,33 & 119,67 & $115,17^{\mathrm{b}}$ \\
\hline Rhizopus sp. & 104,33 & 107,00 & 110,00 & 113,67 & $108,75^{\mathrm{c}}$ \\
\hline Aspergillus sp. + Rhyzopus sp. & 113,3 & 116,67 & 121,00 & 125,33 & $119,08^{\mathrm{a}}$ \\
\hline Rerata (average) & $110,22^{\mathrm{c}}$ & $111,78^{\mathrm{c}}$ & $115,78^{b}$ & $119,56^{\mathrm{a}}$ & \\
\hline
\end{tabular}




\section{Kemuluran kulit}

Hasil analisis statistik menunjukkan bahwa konsentrasi enzim dan jenis jamur penghasil protease tidak berpengaruh nyata terhadap kemuluran kulit domba. Nilai rerata kemuluran kulit domba pada penelitian ini bila dibandingkan dengan nilai kuat tarik kulit pada Tabel 1 menunjukkan angka berbanding terbalik, yaitu kulit yang mempunyai nilai kekuatan tarik yang tinggi akan mempunyai nilai kemuluran yang rendah. Hal ini sesuai dengan pernyataan Kanagy (1977) yang mengatakan bahwa kekuatan tarik dan kemuluran kulit umumnya menunjukkan nilai yang saling berkebalikan, kulit mempunyai nilai kuat tarik yang tinggi biasanya menghasilkan tingkat kemuluran yang rendah, begitu juga sebaliknya. Keseluruhan hasil uji kemuluran kulit samak ini telah memenuhi standar yang telah ditentukan oleh SNI 06-02341989 yaitu kemuluran maksimal untuk kulit samak adalah sebesar $55 \%$.

\section{Suhu kerut kulit}

Hasil analisis variansi faktor konsentrasi dan jenis jamur penghasil protease menunjukkan pengaruh sangat nyata $(\mathrm{P}<0,01)$ terhadap suhu kerut kulit domba. Peningkatan nilai suhu kerut kulit samak domba dengan protease pada proses unhairing disebabkan karena perlakuan enzimatis,

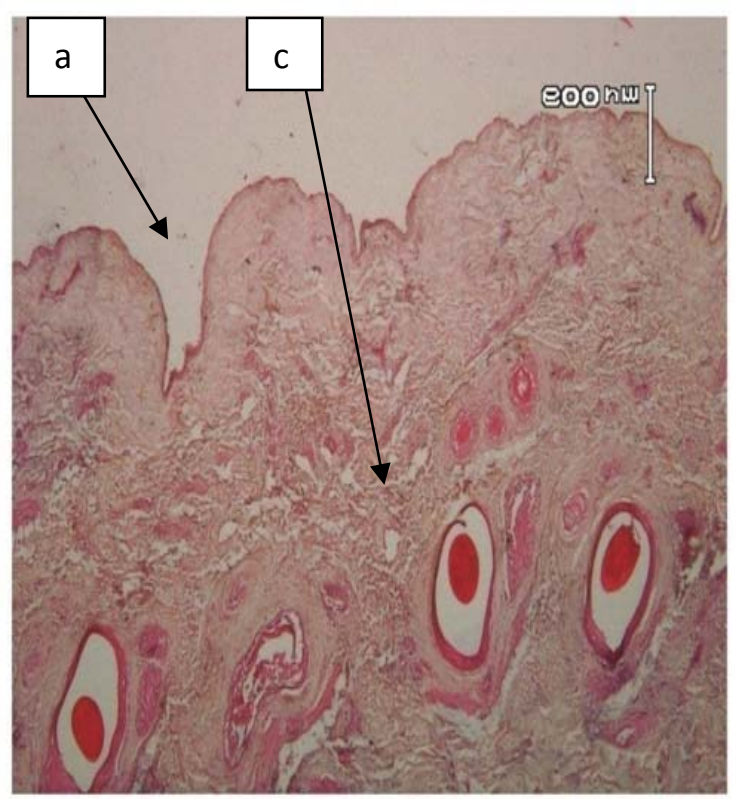

Penampang melintang kulit domba proses unhairing tanpa enzim perbesaran $400 \mathrm{X}$ dimana fungsinya untuk melonggarkan struktur kolagen dan menghilangkan semua protein kulit non kolagen yang tidak dibutuhkan pada proses penyamakan sehingga kulit siap berinteraksi dengan bahan penyamak. Semakin banyak jumlah bahan penyamak yang berikatan maka semakin tinggi suhu kerut kulit (Nayudamma, 1978), selanjutnya dinyatakan pada kulit samak krom, suhu pengkerutan kulit akan meningkat dengan bertambahnya kandungan krom dalam kulit jadi. Interaksi antara konsentrasi enzim dan jenis jamur penghasil protease terhadap nilai suhu kerut memberikan perbedaan yang tidak nyata.

\section{Histologi kulit}

Hasil kenampakan penampang histologi kulit setelah proses unhairing dengan menggunakan protease sebanyak $2,5 \%$ dan $3 \%$, baik Aspergillus sp., Rhizopus sp. dan gabungan dari keduanya menunjukkan bahwa kulit bersih dari sisa-sisa bulu atau rambut (b) serta struktur serabut yang terbukti (d). Hal ini disebabkan karena enzim protease yang digunakan dalam proses unhairing mampu mencerna sel-sel lapisan malphigi juga sel-sel basal sekitar akar bulu/rambut. Protease mampu mencerna soft keratin pada sel-sel lapisan malphigi dan akar rambut, sehingga rambut dapat tercabut sampai akar-akarnya (Triatmojo et al., 2004).

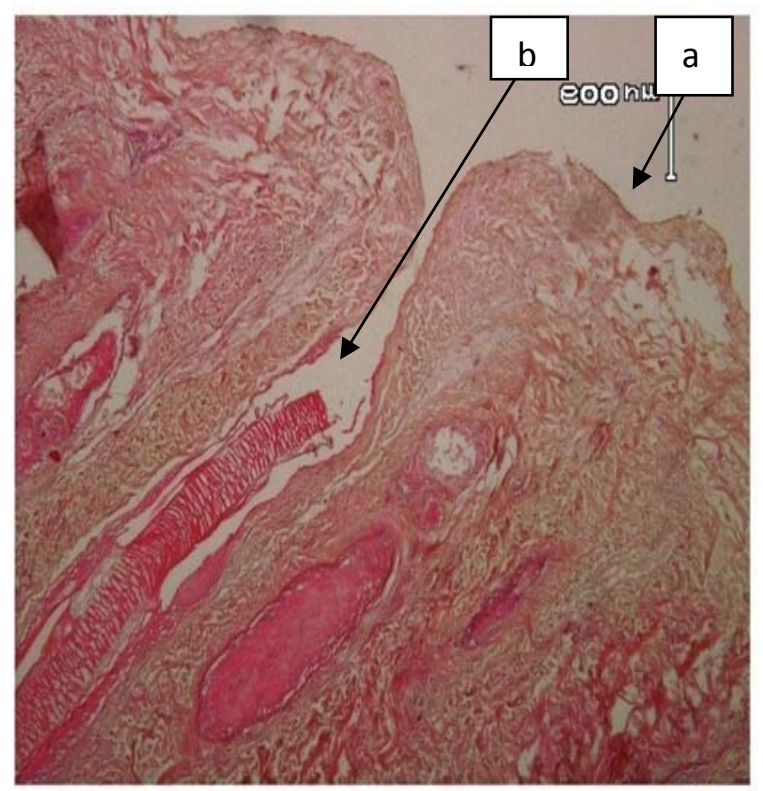

Penampang melintang kulit domba proses unhairing protease Aspergillus sp. perbesaran 400X

Gambar 1. Fotomikrograf penampang melintang kulit domba proses unhairing tanpa enzim dan menggunakan enzim protease Aspergillus sp. $2 \%$ (a. epidermis, b. rambut, c. folikel rambut) (photomicrograph of cross section of sheep leather with unhairing without enzyme and used $2 \%$ enzyme of Aspergillus sp. (a. epidermis, b. hair, c. follicle hair)). 


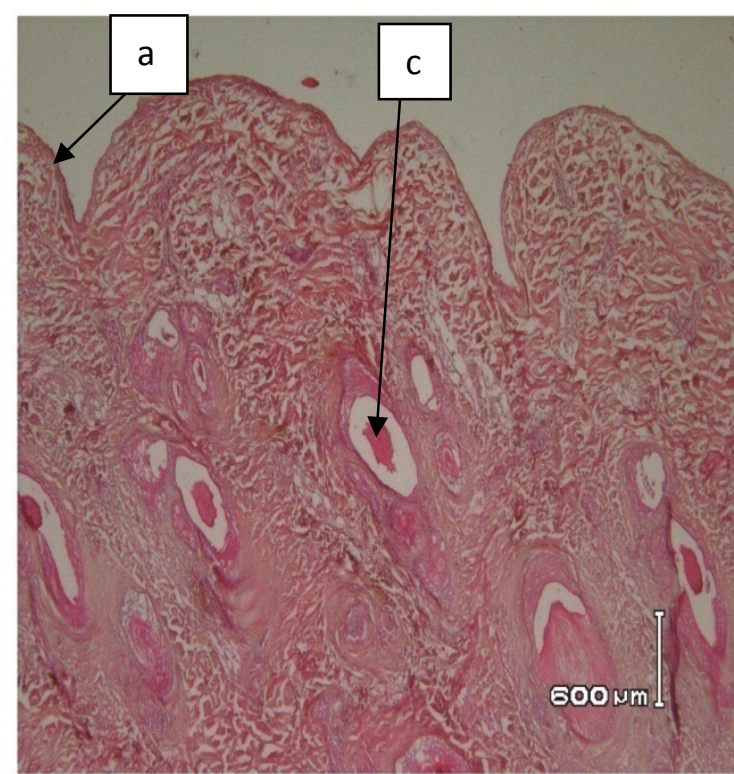

Penampang melintang kulit domba proses unhairing protease Rhizopus sp. 2\% perbesaran $400 \mathrm{X}$

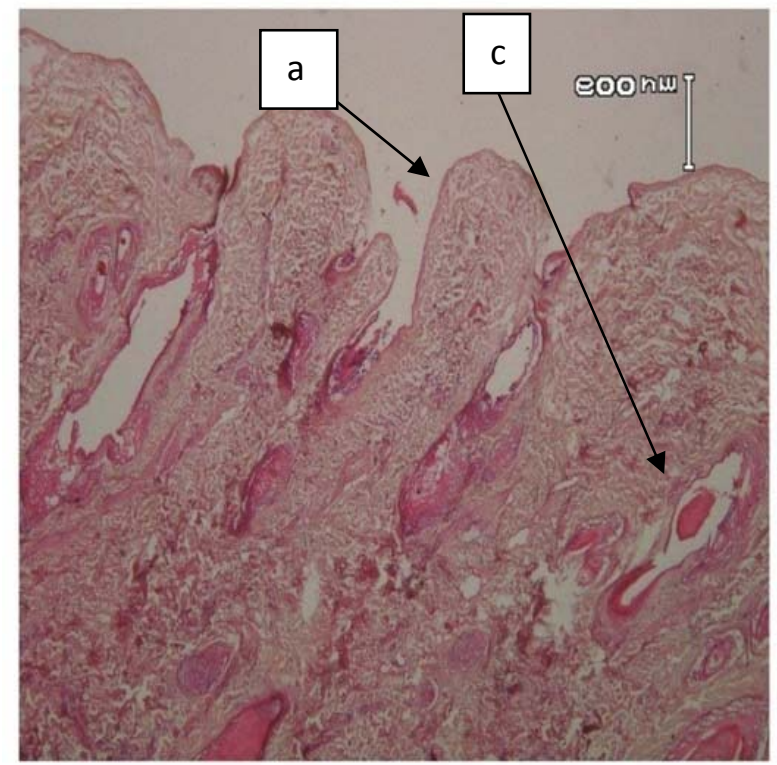

Penampang melintang kulit domba proses unhairing protease Aspergillus sp. dan Rhizopus sp. 2\% perbesaran $400 \mathrm{X}$

Gambar 2. Fotomikrograf penampang melintang kulit domba proses unhairing menggunakan enzim protease Rhizopus sp. 2\% serta gabungan antara Aspergillus sp. dan Rhizopus sp. 2\% (a. epidermis, c. folikel rambut) (photomicrograph of cross section of sheep leather with unhairing process using $2 \%$ protease enzyme of Rhizopus sp. and 2\% enzyme of combined of Aspergillus sp. and Rhizopus sp. (a. epidermis, c. follicle hair)).

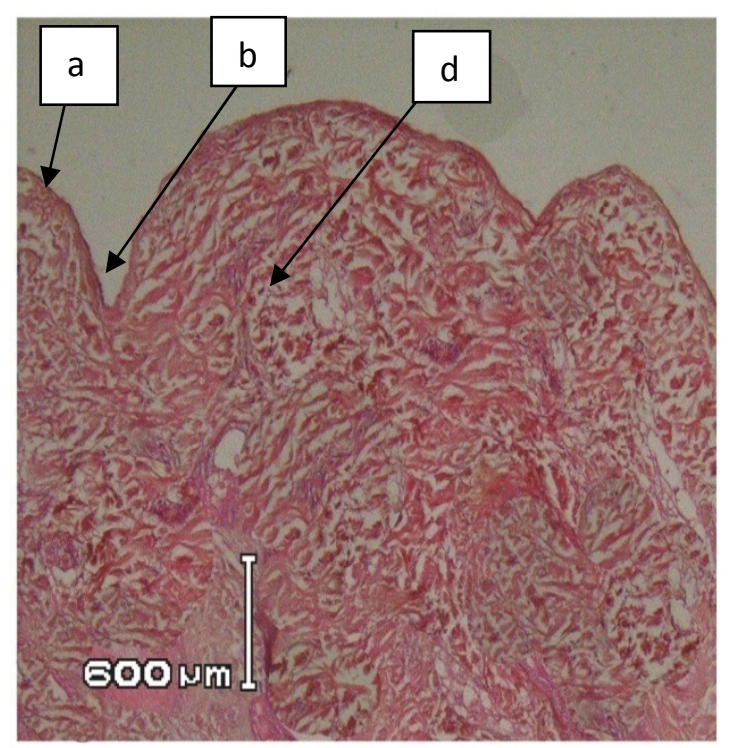

Penampang melintang kulit domba proses unhairing protease Aspergillus sp. 2,5\% perbesaran $400 \mathrm{X}$

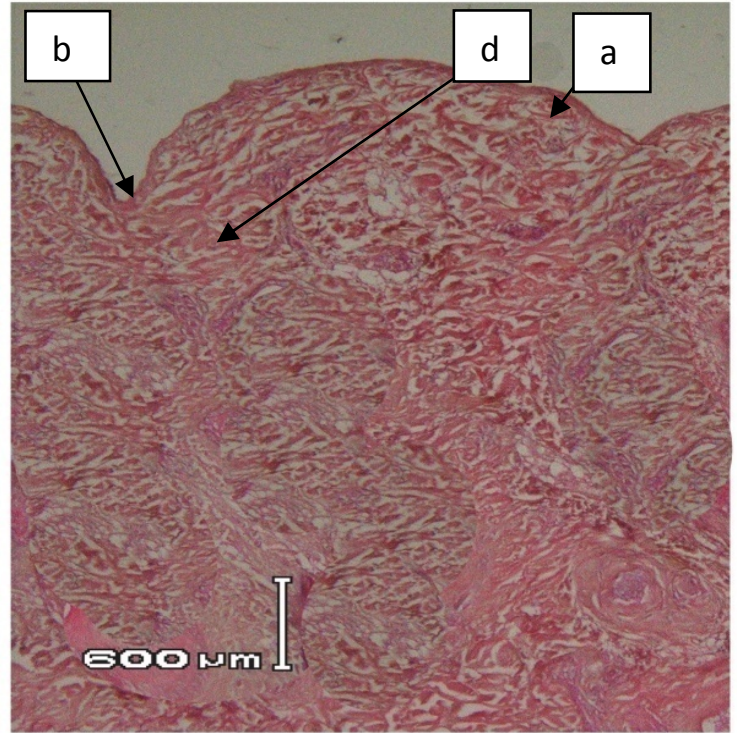

Penampang melintang kulit domba proses unhairing protease Rhizopus sp. 2,5\% perbesaran $400 \mathrm{X}$

Gambar 3. Fotomikrograf penampang melintang kulit domba proses unhairing menggunakan enzim protease Aspergillus sp. 2,5\% dan Rhizopus sp. 2,5\% (a. epidermis, b. rambut, d. struktur kulit/papilar) (photomicrograph of cross section of sheep leather with unhairing process using $2.5 \%$ protease enzyme of Aspergillus sp. and 2.5\% of Rhizopus sp. (a. epidermis, b. hair, $d$. structure of the skin/papillary)). 
Selanjutnya dinyatakan pemakaian enzim untuk proses unhairing adalah rambut yang dihasilkan relatif utuh.

\section{Nilai pH}

Hasil analisis variansi menunjukkan bahwa perlakuan enzimatik Aspergillus sp., Rhizopus sp. dan kombinasi antara Aspergillus sp. dan Rhizopus sp. berpengaruh nyata $(\mathrm{P}<0,05)$ terhadap nilai $\mathrm{pH}$. Pada perlakuan enzimatik, penggunaan Aspergillus sp. dan Rhizopus sp. serta kombinasi antara Aspergillus sp. dan Rhizopus sp. dengan konsentrasi yang berbeda tidak meningkatkan nilai $\mathrm{pH}$ secara signifikan, yaitu sekitar 9,8 sampai 10,4, karena di dalam masa berjamur Aspergillus sp. dan Rhizopus sp. yang ditambahkan juga terdapat bahan organik yang dapat meningkatkan $\mathrm{pH}$. Penambahan kapur pada perlakuan enzimatik untuk menaikkan nilai $\mathrm{pH}$ menjadi 9,5 guna meningkatkan kerja enzim protease Aspergillus sp., Rhizopus sp. dan kombinasi antara Aspergillus sp. dan Rhizopus sp. karena enzim protease dari kedua jenis jamur dapat bekerja pada pH 9,5. Kamini et al. (1998) menyatakan bahwa $\mathrm{pH} 10$ efektif untuk buang rambut, dan penggunaan kapur konsentrasi tinggi akan menghasilkan lingkungan alkalin yang ekstrim.

Penurunan nilai $\mathrm{pH}$ ini menguntungkan dan lebih ramah lingkungan karena mendekati nilai $\mathrm{pH}$

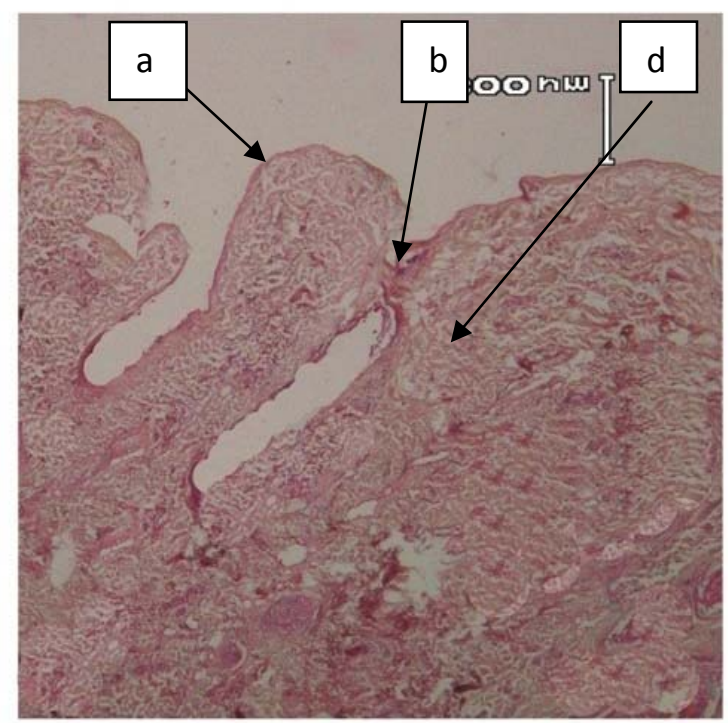

Penampang melintang kulit domba proses unhairing protease Aspergillus sp. dan Rhizopus sp. 2,5\% perbesaran $400 \mathrm{X}$ netral. Semakin tinggi konsentrasi yang digunakan semakin tinggi nilai $\mathrm{pH}$ yang didapat, hal ini disebabkan karena semakin tinggi konsentrasi yang diberikan maka konsentrasi substrat juga makin tinggi, substrat yang merupakan bahan organik akan meningkatkan nilai $\mathrm{pH}$. Tchobanoglous dan Burton (1992) mengatakan bahwa bahan organik akan menambah konsentrasi ion hidrogen dan meningkatkan nilai $\mathrm{pH}$ interaksi anatara konsentrasi enzim dan jenis jamur penghasil protease terhadap nilai $\mathrm{pH}$ memberikan perbedaan yang tidak nyata.

\section{Nilai BOD}

Hasil analisis variansi menunjukkan bahwa perlakuan dengan konsentrasi protease berpengaruh sangat nyata $(\mathrm{P}<0,01)$ terhadap nilai $\mathrm{BOD}$, sedangkan perlakuan dengan jenis jamur dalam penelitian ini memberikan pengaruh yang berbeda tidak nyata terhadap nilai BOD.

Penurunan nilai BOD secara enzimatik pada konsentrasi perlakuan $2 \%, 2,5 \%$, dan $3 \%$ pada penelitian ini dikarenakan enzim mencerna sel basal dari folikel rambut diikuti dengan memecah pelindung akar dari bagian rambut yang bukan keratin, sehingga menyebabkan tercabutnya akar rambut dan terbukanya ikatan serabut, maka rambut dapat terlepas dengan utuh. Selain itu enzim tidak dapat menghancurkan ikatan disulfida pada struktur keratin, maka struktur yang sudah terlepas tidak

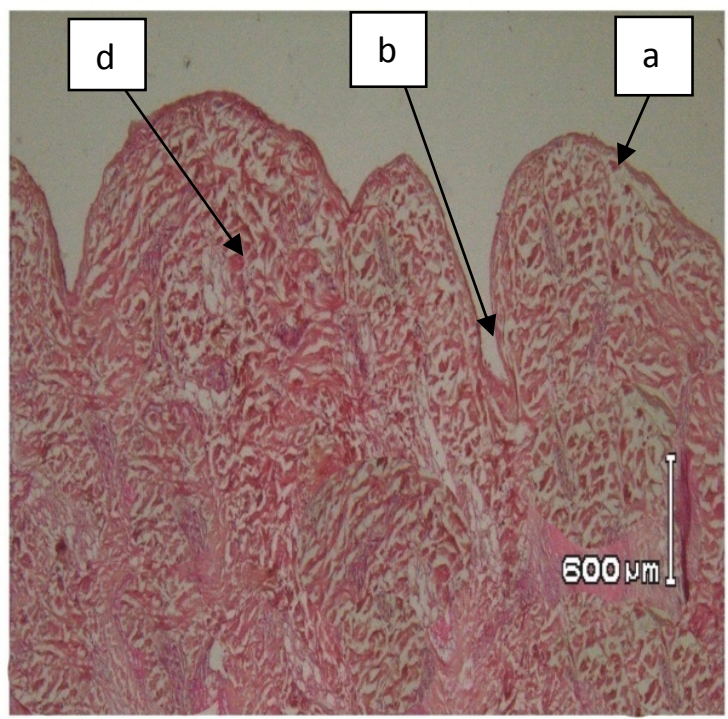

Penampang melintang kulit domba proses unhairing protease Aspergillus sp. 3\% perbesaran $400 \mathrm{X}$

Gambar 4. Fotomikrograf penampang melintang kulit domba proses unhairing menggunakan enzim protease gabungan antara Aspergillus sp. dan Rhizopus sp. 2,5\% serta protease Aspergillus sp. 3\% (a. epidermis, b. rambut, d. struktur kulit/papilar) (photomicrograph of cross section of sheep leather with unhairing process using 2.5\% protease enzyme of combined Aspergillus sp. and Rhizopus sp. and 3\% protease enzyme of Aspergillus sp. (a. epidermis, b. hair, d. structure of the skin/papillary)). 


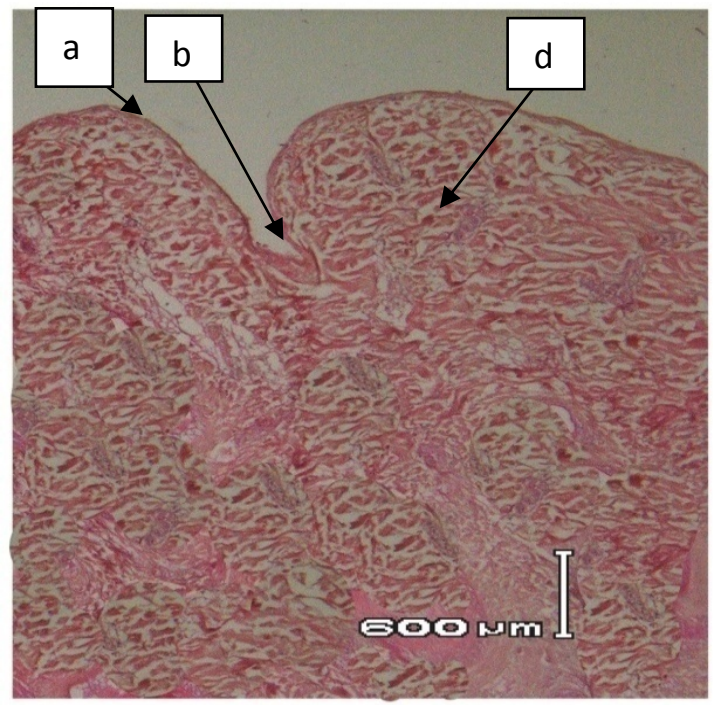

Penampang melintang kulit domba proses unhairing protease Rhizopus sp. 3\% perbesaran $400 \mathrm{X}$

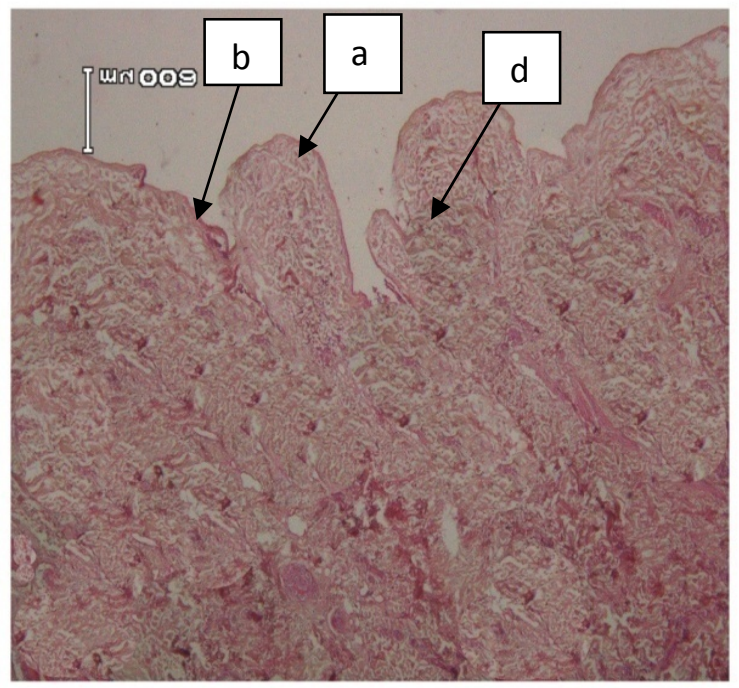

Penampang melintang kulit domba proses unhairing protease Aspergillus sp. dan Rhizopus sp. 3\% perbesaran $400 \mathrm{X}$

Gambar 5. Fotomikrograf penampang melintang kulit domba proses unhairing menggunakan enzim protease Rhizopus sp. 3\% serta gabungan antara Aspergillus sp. dan Rhizopus sp. 3\% (a. epidermis, b. rambut, d. struktur kulit/papilar) (photomicrograph of cross section of sheep leather with unhairing process using 3\% protease enzyme of Rhizopus sp. and 3\% protease enzyme of combined of Aspergillus sp. and Rhizopus sp. (a. epidermis, b. hair, d. structure of the skin/papillary)).

Tabel 2. Rerata nilai kualitas limbah cair samak proses unhairing menggunakan enzim protease Aspergillus sp., Rhizopus sp. serta gabungan Aspergillus sp. dan Rhizopus sp. (average of quality ow waste water of unhairing process using protease enzyme of Aspergillus sp., Rhizopus sp. and combined of Aspergillus sp. and Rhizopus sp.)

\begin{tabular}{|c|c|c|c|c|c|}
\hline \multirow{2}{*}{ Parameter } & \multicolumn{4}{|c|}{ Perlakuan (treatment) } & \multirow{2}{*}{$\begin{array}{c}\text { Rerata } \\
\text { (average) }\end{array}$} \\
\hline & $\mathrm{P} 0$ & $\mathrm{P} 1$ & $\mathrm{P} 2$ & P3 & \\
\hline \multicolumn{6}{|l|}{$\mathrm{pH}$ ( $p H$ value $)$} \\
\hline Aspergillus sp. & 12.67 & 10.37 & 10.40 & 10.53 & $10.99^{\mathrm{a}}$ \\
\hline Rhizopus sp. & 13.00 & 9.73 & 10.80 & 11.33 & $11.21^{\mathrm{a}}$ \\
\hline Aspergillus sp. + Rhizopus sp. & 12.50 & 9.30 & 9.37 & 9.47 & $10.16^{\mathrm{b}}$ \\
\hline Rerata (average) & $12.72^{\mathrm{a}}$ & $9.80^{\mathrm{b}}$ & $10.19^{\mathrm{b}}$ & $10.44^{\mathrm{b}}$ & \\
\hline \multicolumn{6}{|l|}{$\begin{array}{l}\text { Nilai BOD }(\mathrm{mg} / \mathrm{L})(\text { BOD value } \\
(m g / L))^{\mathrm{ns}}\end{array}$} \\
\hline Aspergillus sp. & $19.900,00$ & $6.966,67$ & $6.200,00$ & $5.586,67$ & $9.663,335$ \\
\hline Rhizopus sp. & $19.200,00$ & $7.566,67$ & $6.640,00$ & $5.466,67$ & $9.718,335$ \\
\hline Aspergillus sp. + Rhizopus sp. & $22.666,67$ & $7.090,00$ & $5.566,67$ & $5.440,00$ & $10.190,84$ \\
\hline Rerata (average) & $20.588,89^{\mathrm{a}}$ & $7.207,78^{\mathrm{b}}$ & $6.135,56^{b}$ & $5.497,78^{\mathrm{b}}$ & \\
\hline \multicolumn{6}{|l|}{$\begin{array}{l}\text { Nilai COD }(\mathrm{mg} / \mathrm{L})(\mathrm{COD} \text { value } \\
(m g / L))^{\mathrm{ns}}\end{array}$} \\
\hline Aspergillus sp. & $43.666,67$ & $13.733,33$ & $13.500,00$ & $13.600,00$ & $21.125,00$ \\
\hline Rhizopus sp. & $43.266,67$ & $13.466,67$ & $13.530,67$ & $13.281,00$ & $20.886,25$ \\
\hline Aspergillus sp. + Rhizopus sp. & $44.366,67$ & $13.433,33$ & $13.633,33$ & $13.470,00$ & $21.225,83$ \\
\hline Rerata (average) & $43.766,67^{\mathrm{a}}$ & $13.544,44^{\mathrm{b}}$ & $13.554,67^{\mathrm{b}}$ & $13.450,33^{\mathrm{b}}$ & \\
\hline
\end{tabular}

$\overline{\mathrm{a}, \mathrm{b}}$ Superskrip yang berbeda pada baris yang sama menunjukkan perbedaan $(\mathrm{P}<0,05)$ (different superscripts at the same row indicate significant differences $(P<0.05))$.

ns non significant. 
dapat dihancurkan dan rambut tetap utuh, sehingga limbah yang diperoleh rambutnya tetap utuh dan mudah dipisahkan. Kondisi ini menyebabkan bahan-bahan yang terkandung dalam limbah cair pada proses enzimatik lebih sedikit sehingga oksigen yang dibutuhkan oleh mikroorganisme lebih sedikit untuk mengoksidasi bahan-bahan tersebut dapat menurunkan nilai BOD dalam cemaran.

Triatmojo et al. (2004) menyatakan bahwa enzim protease mampu mencerna soft keratin pada sel-sel lapisan malpigi dan akar rambut, sehingga rambut dapat dicabut sampai ke akar-akarnya. Selanjutnya dikatakan pemakaian enzim untuk proses unhairing adalah rambut yang dihasilkan relatif utuh, mengurangi penggunaan sulfida sekitar 60\% serta menurunkan nilai BOD.

Semakin besar konsentrasi enzim yang digunakan maka semakin rendah nilai BOD yang dihasilkan, karena semakin besar konsentrasi enzim yang digunakan dapat mendegradasi bahan organik. Terjadi penurunan nilai BOD dengan perlakuan enzimatik pada konsentrasi $2 \%, 2,5 \%$ dan $3 \%$ sebesar 7207.78, 6135.56 dan 5497.78, ini menunjukkan bahwa perlakuan enzimatik dapat menurunkan nilai BOD (Gambar 6).

\section{Nilai COD}

Hasil analisis statistik menunjukkan bahwa perlakuan dengan faktor konsentrasi enzim

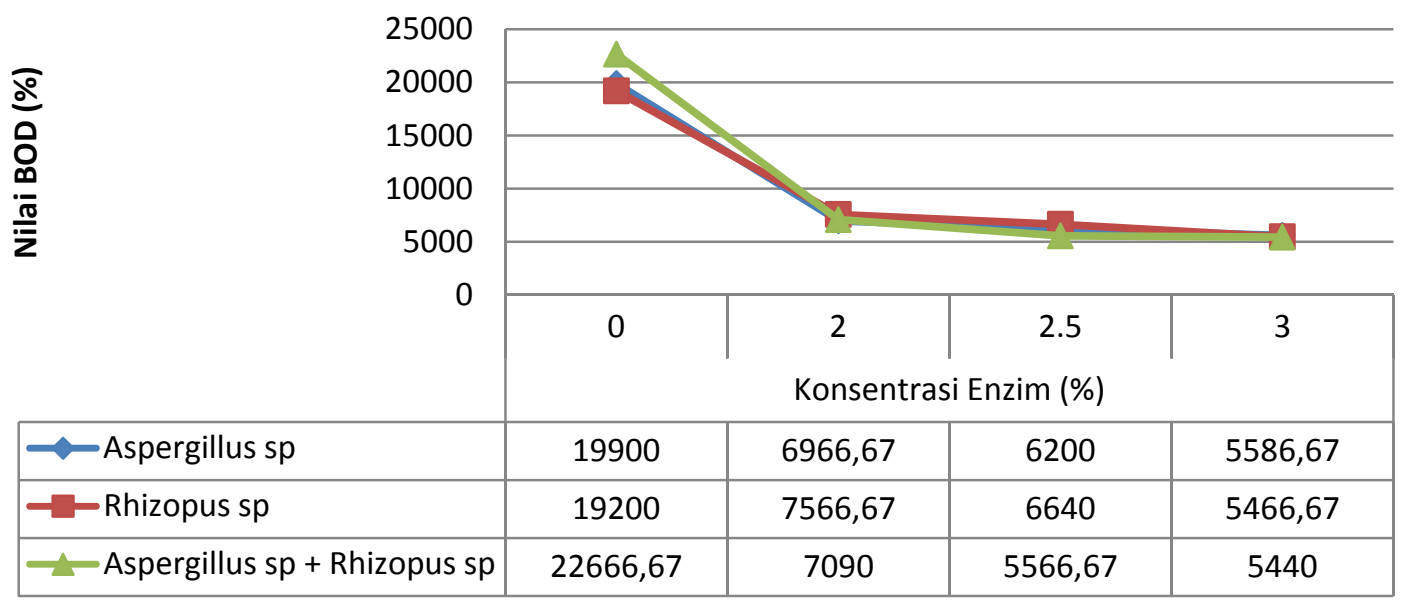

Gambar 6. Grafik nilai BOD limbah cair samak unhairing menggunakan enzim protease Aspergillus sp., Rhizopus sp. serta gabungan Aspergillus sp. dan Rhizopus sp. (graphic of BOD's waste water of unhairing process using protease enzyme of Aspergillus sp., Rhizopus sp. and combined of Aspergillus sp. and Rhizopus sp.).

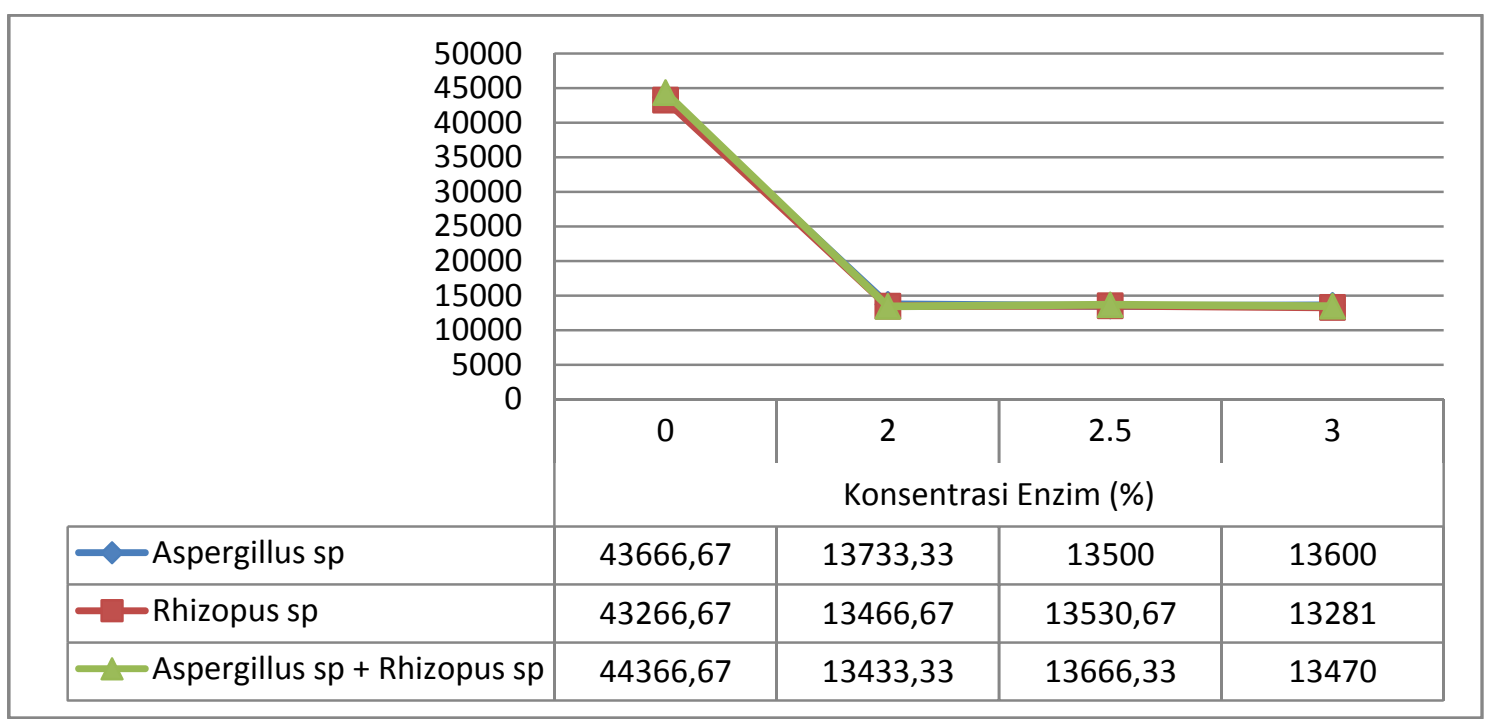

Gambar 7. Grafik nilai COD limbah cair samak unhairing menggunakan enzim protease Aspergillus sp., Rhizopus sp. serta gabungan Aspergillus sp. dan Rhizopus sp. (graphic of COD's waste water of unhairing process using protease enzyme of Aspergillus sp., Rhizopus sp. and combined of Aspergillus sp. and Rhizopus sp.). 
memberikan pengaruh berbeda sangat nyata $(\mathrm{P}<0,01)$ terhadap nilai $\mathrm{COD}$, sedangkan perlakuan dengan faktor jenis jamur pada penelitian ini memberikan pengaruh yang berbeda tidak nyata $(\mathrm{P}>0,05)$ terhadap nilai COD.

Pada perlakuan enzimatik terjadi penurunan nilai $\mathrm{COD}$ yang berbeda sangat nyata $(\mathrm{P}<0.01)$ dengan perlakuan konvensional. Hal ini disebabkan karena bahan-bahan organik yang terkandung dalam limbah cair pada perlakuan enzimatik tidak sebanyak seperti pada perlakuan proses unhairing secara konvensional. Pada proses enzimatik, enzim mencerna sel basal dari folikel rambut diikuti dengan memecah pelindung akar dan bagian dari rambut yang bukan keratin, sehingga menyebabkan tercabutnya akar rambut dan terbukanya ikatan serabut maka rambut dapat terlepas dengan utuh. Kondisi ini menyebabkan bahan-bahan organik yang terkandung dalam limbah cair proses unhairing secara enzimatik dapat disaring. Oleh karena itu kandungan bahan organik dalam limbah cair menjadi sedikit dan oksigen yang diperlukan untuk mengoksidasi bahan-bahan organik tidak banyak.

Perlakuan enzimatik pada penelitian ini sangat potensial karena mampu mengelimenir nilai COD sampai $69 \%$. Hal ini sesuai dengan pernyataan Triatmojo et al. (2004), bahwa pemakaian enzim untuk proses unhairing adalah rambut yang dihasilkan relatif utuh serta dapat menurunkan nilai COD dalam limbah cair sekitar 40-50\% lebih rendah dari pada proses unhairing secara konvensional.

\section{Kesimpulan}

Berdasarkan hasil penelitian maka dapat disimpulkan sebagai berikut: perlakuan konsentrasi protease yang berbeda pada proses unhairing memberikan efek yang positif terhadap kualitas fisik kulit dan limbah cair, perlakuan protease pada konsentrasi $2,5 \%$ dan 3\% dapat meningkatkan nilai kuat tarik dan suhu kerut kulit domba, histologi kulit yang dihasilkan proses unhairing pada konsentrasi 2,5\% dan 3\% masing-masing jenis jamur terlihat struktur kolagen mulai terbuka, kulit bersih dan tidak terdapat sisa rambut yang menempel, perlakuan protease sangat potensial karena dapat menekan hasil limbah BOD dan COD sebesar $69 \%$ pada penelitian ini.

\section{Daftar Pustaka}

Ediari, P., T. P. Widowati, H. Mustofa, T. C. B. Supriyono dan R. J. Susila. 2002. Penerapan protease Rhyzopus sp. pada proses buang bulu ramah lingkungan. Prosiding Seminar Nasional II Industri Kulit, Karet dan Plastik. Balai Besar Penelitian dan Pengembangan Industri Barang Kulit, Karet, dan Plastik, Yogyakarta.

Kamini, N. R., C. Hemachander, J. G. S. Mala and R. Puvanakrishnan. 1998. Microbial Enzymes Technology as an Alternative Chemicals in Leather Industry. Department of Biotechnology, Central Leather Research Institute, Adyar, Chennai, India.

Kanagy. J. R. 1977. Physical and performance properties of leather. In : The Chemistry and Technology of Leather Vol. IV. Edited by: Publishing Company, Huntington, New York. Tchobanoglous, G. and F. L. Burton. 1992. Wastewater Engineering, Treatment, Disposal and Reuse. $3^{\text {rd }}$ ed. McGraw-Hill, Inc. Toronto.

Triatmojo, S., Y. Erwanto, dan N. A. Fitriyanto. 2004. Penerapan protease Aspergillus sp pada proses buang rambut ramah lingkungan. Buletin Peternakan 28: 195-203.

Widowati, T. P., P. Ediari, H. Mustofa, R. J. Susila, dan T. C. B. Supriyono. 2002. Penggunaan protease Rhizopus sp sebagai agensia proses buang bulu. JNK 9: 23-26. 